\title{
PENGARUH PENGGUNAAN RUMPUT LAUT DAN PARE DALAM RANSUM TERHADAP JUMLAH LEUKOSIT DAN PERSENTASE BOBOT BURSA FABRISIUS AYAM BROILER
}

(The Effect of Seaweed and Bitter Melon in Ration on Total Leukocytes and the Percentage Weight of Bursa Fabricius of Broilers)

\author{
Puspitasari, S. ${ }^{1}$ Isroli $^{2}$, dan E. Kusumanti ${ }^{3}$ \\ ${ }^{1)}$ Mahasiswa Jurusan S1 Peternakan Fakultas Peternakan dan Pertanian UNDIP Semarang \\ Kampus drh. Soejono Koesoemowardjojo Tembalang Semarang 50275 \\ E-mail : sandhy_puspitasari@yahoo.com \\ ${ }^{2,3)}$ Staf Pengajar Fakultas Peternakan dan Pertanian, Universitas Diponegoro, Semarang \\ Kampus drh. Soejono Koesoemowardjojo Tembalang Semarang 50275
}

Diterima : 15 Desember 2015

Disetujui : 25 Juni 2016

\begin{abstract}
This research study was aimed to determine the influence of using seaweed (Gracilaria verrucosa) and bitter melon (Momordica charantia) on the total leukocytes and bursa fabricius of broiler chicken. The experiment used 100 DOC (Day Old Chicken) broilers. The rations for broiler consisted of seaweed, bitter melon, bran, soybean meal, poultry meat meal, and topmix. The experimental was design used was a completely randomized design with 4 treatments and 5 replications, each replications consisted of 5 broilers. Rations classified as: TO = control rations without seaweed and bitteer melon, T1 $=$ rations using $2 \%$ bitter melon, $T 2=$ rations using $7 \%$ seaweed, $T 3=$ rations using $2 \%$ bitter melon and 7\% seaweed. The parameters measured were total leukocytes and relative weight of bursa fabricius at 3 weeks age. The results showed that the treatments were significantly affected $(P<0,05)$ total leukocytes, but not $(P>0,05)$ on the relative weight of bursa fabricius. The total leukocytes on T0, T1, T2, T3 is $12,35\left(\times 10^{3} / \mu \mathrm{l}\right), 9,98\left(\times 10^{3} / \mu \mathrm{l}\right)$, $9,02\left(\times 10^{3} / \mu l\right)$, dan $10,81\left(\times 10^{3} / \mu l\right)$, and relative weight of bursa fabricius is $0,28 \%$, $0,25 \%, 0,18 \%$, dan 0,21\%. The conclusion is that the using seaweed and bitter melon in rations can increased endurance were reflacted the normal conditions on the total leukocytes and relatif weight of bursa fabricius.
\end{abstract}

Keywords : bitter melon, seaweed, leukocytes, bursa fabricius.

\begin{abstract}
ABSTRAK
Penelitian ini bertujuan untuk mengetahui pengaruh menggunakan rumput laut (Gracilaria verrucosa) dan pare (Momordica charantia) dari total leukosit dan bursa fabricius ayam broiler. Percobaan menggunakan 100 DOC (Day Old Chicken) ayam pedaging. Ransum untuk broiler terdiri dari rumput laut, pare, dedak, bungkil kedelai, meta meal unggas, dan topmix. Desain percobaan yang digunakan adalah rancangan acak lengkap dengan 4 perlakuan dan 5 ulangan, masing-masing ulangan terdiri dari 5 broiler. Ransum diklasifikasikan sebagai: ransum $\mathrm{T} 0=$ kontrol tanpa rumput laut dan bitteer melon, $\mathrm{T} 1=$ ransum menggunakan $2 \%$ pare, $\mathrm{T} 2=$ ransum menggunakan $7 \%$ rumput laut, $\mathrm{T} 3=$ ransum menggunakan $2 \%$ pare dan $7 \%$ rumput laut. Parameter yang diukur adalah
\end{abstract}


total leukosit dan berat relatif bursa Fabricius pada usia 3 minggu. Hasil penelitian menunjukkan bahwa perlakuan secara signifikan dipengaruhi $(\mathrm{P}<0,05)$ jumlah leukosit, tapi tidak $(\mathrm{P}>0,05)$ pada berat relatif bursa Fabricius. Total leukosit pada T0, T1, T2, T3 adalah 12,35 (× $103 / \mathrm{ml}), 9,98$ (× $103 / \mathrm{ml}), 9,02(\times 103 / \mathrm{ml})$, Dan 10,81 (× $103 / \mathrm{ml})$, dan berat relatif bursa Fabricius adalah 0,28\%, 0,25\%, 0,18\%, dan 0,21\%. Penggunaan rumput laut dan pare sebagai bahan pakan dapat meningkatkan daya tahan tubuh dilihat dari normalnya jumlah leukosit dan bobot relatif bursa fabrisius, serta meningkatkan bobot badan ayam broiler.

Kata kunci: pare, rumput laut, leukosit, bursa Fabricius.

\section{PENDAHULUAN}

Ayam broiler mempunyai peran penting dalam mendukung kecukupan kebutuhan konsumsi daging nasional (Kementerian Pertanian). Oleh sebab itu perlu terus ditingkatkan produksinya. Usaha tersebut dapat ditingkatkan antara lain menggunakan bahan pakan alternatif. Bahan yang dapat digunakan sebagai bahan pakan alternatif dengan ketersediaan yang cukup dan kandungan gizi baik adalah rumput laut dan pare.

Rumput laut (Gracilaria verrucosa) merupakan salah satu sumberdaya alam hayati dari perairan Indonesia yang mengandung beberapa zak aktif, diantaranya betakaroten, B1, B2 dan B12, alkaloid, flavonoid, steroid /triterpenoid, dan tanin (Ditjen PEN, 2013; Siregar et al., 2012). Senyawa alkaloid, flavonoid, steroid /triterpenoid dan tanin diketahui aktif sebagai senyawa antibakteri dan menghambat pertumbuhan bakteri (Ridlo dan Pramesti, 2009).

Pare (Momordica charantia) adalah tanaman yang buahnya pahit mengandung lectin, saponin, flavonoid, polifenol, vitamin C (antioksidan kuat), glikosida cucurbitacin, momordicin, dan charantin (Maliya dan Pratiwi, 2008). Ekstrak etanol buah pare memiliki sifat bakteriostatik yaitu dapat mengahambat pertumbuhan bakteri (Komala et al., 2012). Pare mempunyai berbagai efek terapeutik termasuk anti kanker, anti virus, antibakteri, anti inflamasi, hipolipidemik, hipokolesterolimik, modulator imun, dan anti diabetes (Zhu et al., 2012).

Daya tahan tubuh terhadap serangan penyakit dan keamanan bahan pakan yang dikonsumsi, dapat diketahui melalui perubahan pada organ tubuh serta profil darah. Kecukupan nutrien menyebabkan sistem pertahanan tubuh ternak menjadi lebih baik, fungsi kekebalan dapat dilihat dari variabel darah salah satunya leukosit (Isroli et al., 2009).

Tujuan penelitian adalah untuk mengetahui efek penggunaan rumput laut dan/atau pare terhadap total leukosit, dan bobot bursa fabrisius ayam broiler.

Hipotesis yang dapat dikemukakan adalah dengan penggunaan pare dan/rumput laut dalam ransum dapat meningkatkan daya tahan tubuh yang dapat diukur dari kadar (jumlah) leukosit dan persentase bobot bursa fabrisius yang normal.

\section{MATERI DAN METODE}

Penelitian dilaksanakan bulan Januari sampai dengan bulan Februari 2015 di Fakultas Peternakan dan Pertanian Universitas Diponegoro. Analisis darah dilakukan di Laboratorium Cito Jl. Dr Cipto nomor A4, Semarang. Analisis kandungan bahan pakan dilaksanakan di Laboratorium 
Ilmu Nutrisi Ternak, Fakultas Peternakan dan Pertanian, Universitas Diponegoro, Semarang.

Penelitian menggunakan 100 ekor Day Old Chick (DOC) ayam broiler unsex. Ransum yang diberikan terdiri dari rumput laut, buah pare, jagung kuning, bekatul, bungkil kedelai, PMM (Poultry Meat Meal), topmix yang disusun dengan iso protein $23 \%$ dan iso Energi Metabolisme (EM) $3300 \mathrm{kkal} / \mathrm{kg}$.

Tabel 1. Komposisi dan Kandungan Nutrien Ransum Perlakuan

\begin{tabular}{|c|c|c|c|c|}
\hline \multirow{2}{*}{ Bahan pakan } & \multicolumn{4}{|c|}{ Parameter } \\
\hline & T0 & T1 & T2 & T3 \\
\hline & \multicolumn{4}{|c|}{ 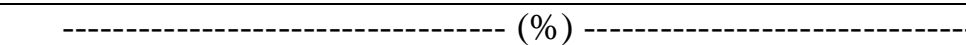 } \\
\hline Rumput Laut & - & - & 7,00 & 7,00 \\
\hline Jagung Kuning & 43,50 & 44,00 & 43,50 & 44,50 \\
\hline Bekatul & 16,60 & 14,00 & 9,50 & 7,20 \\
\hline Bungkil Kedelai & 25,00 & 25,00 & 25,00 & 24,30 \\
\hline PMM & 14,00 & 14,00 & 14,00 & 14,00 \\
\hline Pare & - & 2,00 & - & 2,00 \\
\hline Top Mix & 1,00 & 1,0 & 1,00 & 1,00 \\
\hline Jumlah (\%) & 100 & 100 & 100 & 100 \\
\hline $\mathrm{EM}(\mathrm{kkal} / \mathrm{kg})^{\mathrm{a}}$ & 3299 & 3302 & 3302 & 3304 \\
\hline PK $(\%)^{\mathrm{b}}$ & 23,00 & 23,14 & 23,14 & 23,04 \\
\hline $\mathrm{LK}(\%)^{\mathrm{b}}$ & 4,07 & 3,97 & 3,72 & 3,66 \\
\hline $\mathrm{SK}(\%)^{\mathrm{b}}$ & 4,41 & 4,98 & 5,32 & 5,91 \\
\hline $\mathrm{Ca}(\%)^{\mathrm{b}}$ & 0,87 & 0,88 & 0,90 & 0,91 \\
\hline $\mathrm{P}(\%)^{\mathrm{b}}$ & 0,98 & 0,96 & 0,91 & 0,89 \\
\hline
\end{tabular}

Keterangan:

${ }^{\text {a }}$ Hasil perhitungan menggunakan rumus Balton

Energi Metabolis $=\mathrm{ME}=40,81(0,87(\mathrm{PK}+2,25 \mathrm{LK}+\mathrm{BETN})+2,5)$

${ }^{\mathrm{b}}$ Hasil analisis proksimat di laboratorium ilmu makanan ternak Fakultas Peternakan dan Pertanian Universitas Diponegoro, 2014

Ransum dikelompokkan menjadi 4 perlakuan dan 5 ulangan. Ransum dikelompokkan sebagai berikut:

$\mathrm{T} 0$ = ransum kontrol tanpa rumput laut dan pare,

$\mathrm{T} 1=$ ransum menggunakan $2 \%$ pare

$\mathrm{T} 2=$ ransum menggunakan $7 \%$ rumput laut, $\mathrm{T} 3=$ ransum dengan menggunakan $2 \%$ pare dan $7 \%$ rumput laut.

Perlakuan ransum diberikan sejak ayam umur 1 hari sampai dengan 35 hari. Umur 2 hari dilakukan vaksinasi NDB1 untuk Newcastle Disease melalui tetes mata, umur 7 hari dilakukan vaksinasi Gumboro.
Pengambilan data dilakukan pada saat ayam umur 21 hari meliputi pengambilan darah melalui vena sayap bagian bawah (brachialis) dan bobot relatif bursa fabrisius dari masing-masing unit percobaan. 


\section{HASIL DAN PEMBAHASAN}

Tabel 2. Rataan Jumlah Leukosit, Bobot Relatif Bursa Fabrisius, Bobot Badan dan Konsumsi Ransum Ayam Broiler 21 hari

\begin{tabular}{lcccc}
\hline \hline \multirow{2}{*}{ Parameter } & \multicolumn{4}{c}{ Perlakuan } \\
\cline { 2 - 5 } & $\mathrm{T} 0$ & $\mathrm{~T} 1$ & $\mathrm{~T} 2$ & $\mathrm{~T} 3$ \\
\hline Jumlah leukosit $\left(\times 10^{3} / \mu \mathrm{l}\right)$ & $12,35^{\mathrm{a}}$ & $9,98^{\mathrm{ab}}$ & $9,02^{\mathrm{b}}$ & $10,81^{\mathrm{a}}$ \\
Bobot bursa fabrisius $(\%)$ & 0,28 & 0,25 & 0,18 & 0,21 \\
Bobot Badan (g/ekor) & $388,68^{\mathrm{B}}$ & $439,36^{\mathrm{AB}}$ & $551,29^{\mathrm{A}}$ & $541,12^{\mathrm{A}}$ \\
Konsumsi Ransum (g/ekor/hari) & 44,23 & 43,11 & 45,25 & 45,01 \\
\hline
\end{tabular}

Keterangan : Huruf kecil yang berada dibelakang angka pada baris yang sama menunjukkan berbeda nyata $(\mathrm{P}<0,05)$, huruf besar yang berada dibelakang angka pada baris yang sama menunjukkan berbeda sangat nyata $(\mathrm{P}<0,01)$.

\section{Pengaruh Perlakuan terhadap Jumlah} Leukosit

Hasil analisis ragam jumlah leukosit akibat penggunaan rumput laut dan/atau pare sebagai bahan pakan menunjukkan terdapat pengaruh nyata $(\mathrm{P}<0,05)$ terhadap jumlah leukosit ayam broiler umur 21 hari. T2 (7\% rumput laut) berbeda nyata dengan T0 (kontrol).

Terdapat perbedaan nyata jumlah leukosit antara ransum kontrol dengan ransum yang menggunakan rumput laut. Ransum yang menggunakan rumput laut memiliki jumlah leukosit paling rendah. Hal tersebut menunjukkan bahwa senyawa aktif yang terkandung dalam rumput laut dapat membantu peran leukosit sehingga leukosit yang terbentuk dalam jumlah normal dan tidak meningkat. Siregar et al. (2012) menyatakan golongan senyawa alkaloid, flavonoid, steroid/triterpenoid, dan tanin yang terdapat pada ekstrak kasar rumput laut diduga aktif sebagai senyawa antibakteri. Melki et al. (2011) menyatakan mekanisme penghambatan mikroorganisme oleh senyawa antimikroba yang terkandung dalam rumput laut dapat disebabkan oleh beberapa faktor antara lain gangguan pada senyawa penyusun dinding sel, peningkatan permeabilitas membran sel yang dapat menyababkan kehilangan komponen penyusun sel, menginaktivasi enzim, dan destruksi atau kerusakan fungsi material genetik.

Jumlah leukosit ayam broiler umur 3 minggu berkisar antara 9,98-14,31 ×10 $3 / \mu 1$. Leukosit dapat dijadikan salah satu indikator pertahanan tubuh, jika jumlah leukosit meningkat artinya terdapat peningkatan produksi sel dalam melawan benda asing didalam tubuh. Jumlah leukosit dapat dipengaruhi beberapa faktor. Triana dan Nurhidayat (2006) berpendapat bahwa peningkatan jumlah leukosit dapat terjadi karena pengaruh fisiologis yang dapat disebabkan oleh aktivitas otot, rangsang ketakutan, dan stress, serta pengaruh patologis dapat disebabkan oleh tanggap terhadap serangan penyakit. Sturkie dan Griminger dikutip dalam Rosmalawati (2008) menambahkan jumlah leukosit dapat dipengaruhi oleh jenis kelamin, stress, pakan, umur, lingkungan, dan obat-obatan.

\section{Pengaruh Perlakuan terhadap Bobot Relatif Bursa Fabrisius}

Hasil analisis ragam terhadap bobot bursa fabrisius menunjukkan penggunaan rumput laut dan/atau pare sebagai bahan pakan tidak memberikan pengaruh yang 
nyata terhadap bobot bursa fabrisius ayam broiler. Rataan bobot relatif bursa fabrisius pada penelitian berkisar antara 0,18\% $0,28 \%$. Penggunaan rumput laut dan/atau pare dalam ransum secara umum tidak mengganggu pertumbuhan bursa fabrisius. Penggunaan rumput laut dan/atau pare sebagai bahan pakan dapat memicu kekebalan yang terbentuk karena suplai limfosit yang dibentuk bursa fabrisius untuk menghasilkan antibodi dapat dikurangi. Apriliyani et al. (2013) mengemukakan bahwa apabila bobot bursa pada perlakuan lebih rendah dibanding kontrol bukan berarti ketahanan tubuh broiler menurun. Secara kuantitas bobot relatif yang lebih rendah diduga disebabkan karena bursa fabrisius tidak bekerja hiperaktif dalam menghasilkan antibodi karena peran antibodi dibantu oleh zat aktif. Dalam hal ini peran bursa fabrisius dibantu oleh zat aktif yang terdapat dalam rumput laut dan/atau pare yang bekerja merusak mikroorganisme atau benda asing sehingga bursa fabrisius ada dalam bobot relatif yang normal.

Bobot bursa fabrisius dipengaruhi tipe, galur, kondisi ayam sedangkan kecepatan tumbuh dan besar pada anak ayam ada hubungannya pada resistensi terhadap penyakit (Glick, 2000) dalam Jamin, 2012. Secara absolut bobot relatif bursa fabrisius paling tinggi terdapat pada T0 (ransum kontrol) yang diduga ternak berusaha membentuk antibodi sendiri tanpa adanya bantuan zat aktif yang terdapat pada rumput laut dan pare sehingga meningkatkan kerja bursa fabrisius serta bobot relatifnya. Hal ini didukung dengan data bobot badan pada T0 paling rendah dari pada T1, T2 dan T3 walaupun data konsumsi menunjukkan tidak berbeda nyata.
Hasil analisis ragam menunjukkan adanya perbedaan sangat nyata bobot badan antar perlakuan. Rataan bobot badan T2 (7\% rumput laut) berbeda nyata terhadap perlakuan T0 (kontrol). Perlakuan T3 (2\% pare dan $7 \%$ rumput laut) berbeda nyata dengan T0 (kontrol). Peningkatan bobot badan pada T2 dikarenakan tingkat konsumsi T2 yang tinggi pula. Tillman et al. dalam Horhoruw et al. (2009) menjelaskan rumput laut mengandung iodium yang diketahui iodium merupakan mineral esensial penyusun hormon tiroksin oleh kelenjar tiroid, hormon ini mengatur pertumbuhan dengan merangsang metabolisme di dalam jaringan, serta meningkatkan konsumsi. Rumput laut mengandung beberapa asam amino yang dibutuhkan bagi pertumbuhan unggas. Ma'ruf et al. (2013) menyatakan rumput laut $G$. verrucosa mengandung asam amino berupa glutamic acid, serine, threonine dan glycine, alanine, arginine, valine, leucine, dan lycine. Ariyanto et al. (2013) menjelaskan bahwa pertambahan bobot badan yang baik dicapai bukan ditentukan oleh kadar protein kasarnya, melainkan kelengkapan asam amino yang terkandung dalam ransum serta tingkat konsumsi pakannya. Pada penelitian Situmorang et al., (2013) penggunaan 5\% rumput laut jenis $G$. verrucosa dalam ransumnya dapat menaikkan bobot badan sebesar $0,44 \%$ jika dibanding pada perlakuan yang mendapat ransum kontrol dan mengemukakan bahwa penggunaan rumput laut lebih efisien jika dibanding kontrol serta rumput laut memiliki kandungan gizi lengkap yang dapat meningkatkan bobot badan ayam broiler.

Konsumsi terendah pada ransum menggunakan $2 \%$ pare yang diduga dapat menurunkan palatabilitas pakan karena pare mengandung cucurbitacin menimbulkan 
rasa pahit yang tidak disukai ternak. Dewi (2008) melaporkan dengan penambahan pare $10 \%$ pada tikus belum dapat memberikan pengaruh nyata terhadap tingkat konsumsi ransum, walaupun banyak literatur yang mengatakan pare dapat meningkatkan nafsu makan. Walaupun secara statistik tingkat konsumsi ransum tidak berbeda nyata namun jika dilihat penggunaan pare lebih efisien dari kontrol. Dengan tingkat konsumsi yang lebih rendah dapat meningkatkan bobot badan lebih tinggi dari pada kontrol. Secara absolut tingkat konsumsi tertinggi pada perlakuan penggunaan rumput laut yang dibarengi dengan tingginya bobot badan.

\section{KESIMPULAN DAN SARAN}

\section{Kesimpulan}

Penggunaan rumput laut dan pare sebagai bahan pakan dapat meningkatkan daya tahan tubuh dilihat dari normalnya jumlah leukosit dan bobot relatif bursa fabrisius, serta meningkatkan bobot badan ayam broiler.

\section{Saran}

Perlu studi lebih lanjut berkaitan dengan penggunaan rumput laut dan pare sebagai bahan pakan dilihat dari aspek fisiologis yang lain pada ayam broiler.

\section{DAFTAR PUSTAKA}

Apriliyani, F., N. Suthama dan H. I. Wahyuni. 2013. Rasio heterofil limfosit dan bobot relatif bursa fabrisius akibat kombinasi lama pencahayaan dan pemberian porsi ransum berbeda pada ayam broiler. J. Anim. Agric. 2(1) : 393-399.
Ariyanto, A. N., N. Iriyanti, dan M. Mufti. 2013. Pemanfaatan tepung kunyit (Curcuma domestica val) dan sambiloto (Andrographis paniculata nes) dalam pakan terhadap konsumsi pakan dan pertumbuhan bobot badan broiler. J. Ilmiah Peternakan. 1(2) : 471-478.

Dewi, N. W S. 2008. Kajian Pemberian Tepung Buah Pare (Momordica charantia) Terhadap Konsumsi, Kecernaan Bahan Kering dan Performa Tikus (Rattus norvegicus). Skripsi. Institut Pertanian Bogor. Bogor.

Ditjen Pengembangan Ekspor Nasional (PEN). 2013. Rumput Laut Indonesia. Warta Ekspor. http://djpen.kemendag.go.id.

Diakses tanggal 15 Maret 2015.

Horhoruw, W. M., T. Handoyo dan T. Yuwanta. Pengaruh pemanfaatan rumput laut Gracilaria edulis dalam pakan terhadap kinerja ayam fase pullet. Buletin Peternakan. 33(1): 816.

Isroli, S. Susanti, E. Widiastuti, T. Yudiarti dan Sugiharto. 2009. Observasi beberapa hematologis ayam kedu pada pemeliharaan intensif. Seminar Nasional Kebangkitan Peternakan. 548-557.

Jamin, F. 2012. Akibat infeksi Candida albicans dan pemberian kortikosteroid menyebabkan kondisi imunosupresi organ bursa fabrisius pada ayam pedaging. J. Ilmiah Pendidikan Biologi. 4(2) : 67-71.

Kementrian Pertanian. 2013. Konsumsi Rata-Rata per Kapita Setahun Beberapa Bahan Makanan di Indonesia. www.pertanian.go. id/Indikator/tabe-15b-konsumsirata.pdf. Diakses tanggal 17 Maret 2015

Komala, O., B. L. Sari dan N. Sakinah, 2012. Uji efektifitas ekstrak etanol 
buah pare (Momordica charantia) sebagai antibakteri (Salmonella typhi). Fitofarmaka. 2 (1): 36-41.

Ma'ruf, W. F., R. Ibrahim, E. N. Dewi, E. Susanto, U. Amalia. 2013. Profil rumput laut Caulerpa racemosa dan Gracilaria verrucosa sebagai edible food. J. Saintek Perikanan. 9 (1): 68-74.

Maliya, A. dan A. Pratiwi. 2008. Pengaruh pemberian perasan pare terhadap profil lipid serum tikus wistar. $J$. Kesehatan. 1 (2): 91-96.

Melki,. W. Ayu, dan Kurniati. 2011. Uji antibakteri ekstrak Gracilaria sp. (rumput laut) terhadap bakteri Escherichia coli dan Staphilococcus aureus. http://eprints.unsri.ac.id. Diakses tanggal 24 Agustus 2013.

Ridlo, A. dan R. Pramesti. 2009. Aplikasi ekstrak rumput laut sebagai agen imunostiulan sistem pertahanan non spesifik pada udang (Litopinnaeus vannamei). Ilmu Kelautan. 14 (3): 133-137.

Rosmalawati, N. 2008. Pengaruh Penggunaan Tepung Daun Sembung (Blumea balsamifera) dalam ransum terhadap profil darah ayam broiler periode finisher. Skripsi. Fakultas Peternakan. Institut Pertanian Bogor. Bogor.

Siregar, A. F., A. Sabdono, dan D. Pringgenies. 2012. Potensi antibakteri ekstrak rumput laut terhadap bakteri penyakit kulit Pseudomonas aeruginos, Staphylococcus epidermis, dan Micrococcusluteus. J. of Marine Research. 1(2) : 152-160.

Situmorang, N.A., L.D.Mahfudz, dan U. Atmomarsono. 2013. Pengaruh pemberian tepung rumput laut (Gracilaria verrucosa) dalam ransum terhadap efisiensi penggunaan protein ayam broiler. $J$. Anim. Agric. 2 (2): 49-56.
Triana, E. dan N. Nurhidayat. 2006. Pengaruh pemberian beras yang difermentasi oleh Monascus purpureus jmba terhadap darah tikus putih (Rattus Sp.) hiperkolesterolemia. 7 (4): 317-321.

Zhu, Y., Y. Dong, X. Qian, F. Cui, Q. Guo, X. Zhou, Y. Wang, Y. Zhang dan Z. Xiang. 2012. Effect of superfine grinding on antidiabetic activity of bitter melon powder. International Journal of Molecular Sciences. 13 (11): 14203-14218. 